\title{
EVALUASI KINERJA LEMBAGA PENJAMINAN MUTU INSTITUT AGAMA ISLAM MUHAMMADIYAH SINJAI
}

\author{
Oleh \\ Nurjannah $^{1}$, Irmayanti ${ }^{2}$, Mirna $^{3}$ \\ ${ }^{123}$ Institut Agama Islam Muhammadiyah Sinjai \\ 1nurjannah310807@gmail.com
}

diterima 10 Januari 2021, direvisi 17 Januari 2021, diterbitkan 28 Pebruari 2021

\begin{abstract}
The purpose of the higher education quality assurance system is to ensure that all higher education standards run systematically and continue in a sustainable manner. Therefore, it is hoped that a quality culture will grow and develop in the university environment. In implementing the Quality Assurance System, Islamic Institute of Muhammadiyah Sinjai has a Quality Assurance Agency (LPM) which is tasked with implementing the SPMI. LPM as the organizer of SPMI acts as a tutor, facilitator, internal consultant, quality control and referee for the operations of all existing units. The evaluation was carried out in the form of distributing questionnaires filled out by the academic community which included the ability of LPM staff to meet document needs, the reliability of LPM staff in serving users, socialization of LPM product information, evaluation and monitoring of guidelines or standards, publication of evaluation results and monitoring of guidelines or standards, follow up evaluation and monitoring, service speed of LPM members, accuracy of service schedule implementation, and accuracy of completing tasks.
\end{abstract}

\section{Keywords: Evaluation, LPM, SPMI}

\section{PENDAHULUAN}

Sistem Penjaminan Mutu Internal (SPMI) perguruan tinggi memiliki peranan yang sangat penting bagi setiap perguruan tinggi untuk menjamin mutu pendidikannya. Hal ini tertuang dalam Permenristekdikti No. 62 tahun 2016 tentang Sistem Penjaminan Mutu Pendidikan Tinggi (SPM Dikti) bahwa Sistem Penjaminan Mutu Internal adalah salah satu upaya untuk meningkatkan mutu pendidikan perguruan tinggi. Sistem Penjaminan Mutu Internal (SPMI) adalah keseluruhan rangkaian kegiatan yang dilakukan sebagai bentuk perwujudan akuntabilitas dan transparansi pengelolaan perguruan tinggi (Sulaiman \& Wibowo, 2016; Umami, 2019). SPMI ini mencakup keseluruhan aspek penyelenggaraan 
pendidikan dengan memanfaatkan berbagai sumberdaya yang ada untuk mencapai Standar Nasional Pendidikan (SNP) (Jamaluddin \& Sopiah, 2018).

Tujuan sistem penjaminan mutu pendidikan tinggi adalah untuk menjamin seluruh standar pendidikan tinggi berjalan secara sistematik dan terus berlanjut secara berkelanjutan. Oleh karena itu, budaya mutu diharapkan akan tumbuh dan berkembang pada lingkungan perguruan tinggi. Sistem penjaminan mutu ini dilakukan oleh perguruan tinggi untuk mengendalikan penyelenggaraan pendidikan tinggi sesuai standar penetapan pemerintah (Arifuddin, 2019). Selain itu, tujuan penjaminan mutu pendidikan ialah untuk merencanakan, mencapai, memelihara, dan meningkatkan mutu pendidikan secara berkelanjutan pada satuan pendidikan tertentu (Rusman, 2009).

Implementasi sistem penjaminan mutu pendidikan hingga saat ini masih menghadapi berbagai macam permasalahan antara lain: (1) belum tersosialisasikannya secara utuh Standar Nasional Pendidikan sebagai acuan mutu pendidikan; (2) pelaksanaan penjaminan dan peningkatan mutu pendidikan masih terbatas pada pemantauan komponen mutu di satuan pendidikan; (3) pemetaan mutu masih dalam bentuk pendataan pencapaian mutu pendidikan yang belum terpadu dari berbagai penyelenggara pendidikan; dan (4) tindak lanjut hasil pendataan mutu pendidikan yang belum terkoordinir dari para penyelenggara dan pelaksana pendidikan pada berbagai tingkatan (Haryono dkk, 2019).

Penjaminan mutu Pendidikan telah diatur sedemikian rupa berdasarkan peraturan pemerintah Nomor 19 Tahun 2005 yang menyatakan bahwa setiap satuan Pendidikan baik itu jalur formal maupun non formal wajib melakukan penjaminan mutu Pendidikan (Gustini \& Mauly, 2019).
Dalam melaksanakan Sistem Penjaminan Mutu, Institut Agama Islam Muhammadiyah Sinjai memiliki Lembaga Penjaminan Mutu (LPM) yang bertugas untuk mengimplementasikan SPMI. LPM sebagai penyelenggara SPMI bertindak sebagai tutor, fasilitator, konsultan internal, quality control dan wasit bagi operasional seluruh unit-unit yang ada. Artinya, LPM berbeda dengan unitunit lain yang hanya fokus pada kinerjanya sendiri, tetapi LPM juga fokus pada kinerja mutu unit-unit lain dikarenakan adanya hubungan resiprokal yang sangat kuat (Suci, 2017). LPM harus mempunyai dokumendokumen terkait diantaranya dokumen kebijakan, dokumen manual mutu, dokumen standar dalam SPMI, dan dokumen formulir SPMI (Trianto, 2020). Dokumen-dokumen ini terkait dengan pelaksanaan PPEP yakni penetapan, pelaksanaan, evaluasi, pengendalian, dan peningkatan (Triyana, 2007).

Standar akademik dan non akademik yang telah ditetapkan dalam SPMI wajib dilaksanakan untuk menjamin peningkatan mtu Pendidikan dari masing-masing perguruan tinggi (Trianto, 2020). Standar nasional dikti yang harus digunakan oleh peruguran tinggi mengacu kepada Permendikbud No. 3 tahun 2020 tentang Standar Nasional Pendidikan Tinggi yang memuat 24 standar yang telah ditetapkan oleh kementerian. Trianto (2020) mengemukakan bahwa 24 standar dikti tersebut merupakan standar minimal yang harus dijalankan dan diharapkan dapat dilampaui oleh setiap perguruan tinggi dimana standar tersebut mengacu kepada visi misi tujuan perguruan tinggi, kearifan lokal, hasil tracer studi dan lain-lain.

Keseluruhan tanggung jawab di atas harus dilaksanakan oleh Lembaga Penjaminan Mutu sehingga mutu IAI Muhammadiyah Sinjai dapat meningkat 
setiap tahunnya. Olehnya itu, diperlukan evaluasi untuk mengetahui kinerja Lembaga Penjaminan Mutu setiap semester. Evaluasi ini dilakukan pada setiap akhir semester. Evaluasi dilakukan sebagai acuan peningkatan kualitas serta bentuk pengukuran tingkat keberhasilan layanan atau kinerja Lembaga (Nurjannah, 2020).

\section{METODE}

Evaluasi yang dilakukan berupa penyebaran kuesioner yang diisi oleh civitas akademika yang memuat tentang (1) kemampuan staf LPM memenuhi kebutuhan dokumen, (2) kehandalan staff LPM dalam melayani pengguna, (3) sosialisasi informasi produk LPM, (4) evaluasi dan monitoring pedoman atau standar, (5) publikasi hasil evaluasi dan monitoring pedoman atau standar, (6) follow up evaluasi dan monitoring, (7) kecepatan pelayanan anggota LPM, (8) ketepatan pelaksanan jadwal pelayanan, serta (9) ketepatan menyelesaikan tugas (LPM, 2018).

\section{PEMBAHASAN}

Evaluasi ini dilakukan untuk mengetahui kinerja Lembaga Penjaminan Mutu Institut Agama Islam Muhammadiyah Sinjai semester genap tahun akademik 2019/2020. Penyebaran angket dilakukan setiap semester secara online dengan bantuan google formulir. Adapun indikator evaluasi kinerja Lembaga Penjaminan Mutu yaitu kemampuan staf LPM memenuhi kebutuhan dokumen, kehandalan staff LPM dalam melayani pengguna, sosialisasi informasi produk LPM, evaluasi dan monitoring pedoman atau standar, publikasi hasil evaluasi dan monitoring pedoman atau standar, follow up evaluasi dan monitoring, kecepatan pelayanan anggota LPM, ketepatan pelaksanan jadwal pelayanan dan ketepatan menyelesaikan tugas. Berdasarkan hasil angket yang disebar ada 40 respenden dengan pilihan jawaban ada 5 yaitu 1 (tidak baik), 2 (kurang baik), 3 (cukup baik), 4 (baik) dan 5 (sangat baik). Adapun diagram dan penjelasan hasil evaluasi kinerja Lembaga Penjaminan Mutu IAI Muhammadiyah Sinjai semester genap tahun akademik 2019/2020 sebagai berikut.

\section{Kemampuan staf LPM memenuhi} kebutuhan dokumen

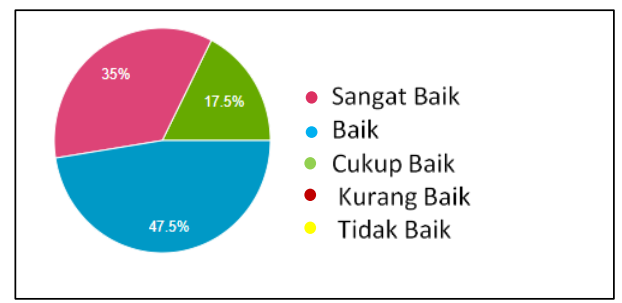

Gambar 1. Diagram kemampuan Staf LPM memenuhi kebutuhan Dokumen

Berdasarkan hasil angket evaluasi kinerja lembaga penjaminan IAIM Sinjai dengan indikator kemampuan staf LPM memenuhi kebutuhan dokumen terdapat $17,5 \%$ cukup baik, $47,5 \%$ baik dan $35 \%$ sangat baik.

2. Kehandalan staff LPM dalam melayani pengguna

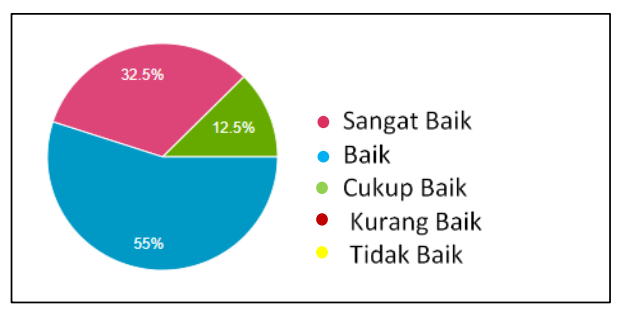

Gambar 2. Diagram kehandalan Staf LPM dalam melayani pengguna

Berdasarkan hasil angket evaluasi kinerja lembaga penjaminan IAIM Sinjai dengan indikator kehandalan staff LPM dalam melayani pengguna terdapat 12,5 $\%$ cukup baik, $55 \%$ baik dan 32,5\% sangat baik. 
3. Sosialisasi informasi produk LPM

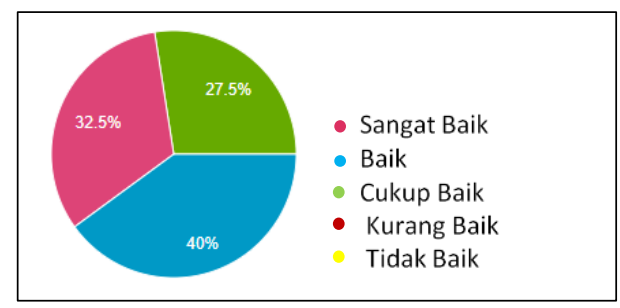

Gambar 3. Diagram Sosialisasi Informasi Produk LPM

Berdasarkan hasil angket evaluasi kinerja lembaga penjaminan IAIM Sinjai dengan indikator sosialisasi informasi produk LPM terdapat 27,5 \% cukup baik, $40 \%$ baik dan $32,5 \%$ sangat baik.

4. Evaluasi dan monitoring pedoman atau standar

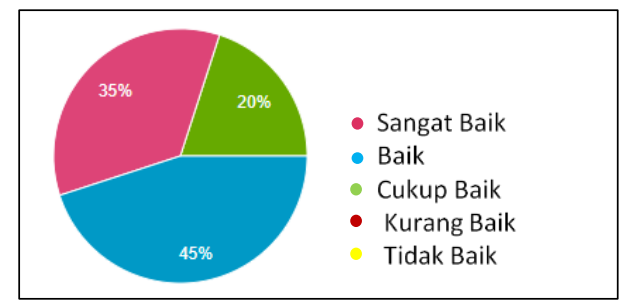

Gambar 4 Diagram Evaluasi dan monitoring pedoman atau standar

Berdasarkan hasil angket evaluasi kinerja lembaga penjaminan IAIM Sinjai dengan indikator evaluasi dan monitoring pedoman atau standar terdapat $20 \%$ cukup baik, $45 \%$ baik dan $35 \%$ sangat baik.

\section{Publikasi Hasil Evaluasi dan} Monitoring Pedoman atau Standar

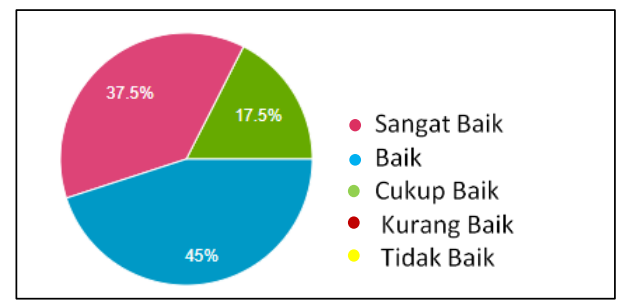

Gambar 5 Diagram Publikasi hasil evaluasi dan monitoring pedoman atau standar

Berdasarkan hasil angket evaluasi kinerja lembaga penjaminan IAIM Sinjai dengan indikator publikasi hasil evaluasi dan monitoring pedoman atau standar terdapat $17,5 \%$ cukup baik, $45 \%$ baik dan $37,5 \%$ sangat baik.

\section{Follow up Evaluasi dan Monitoring}

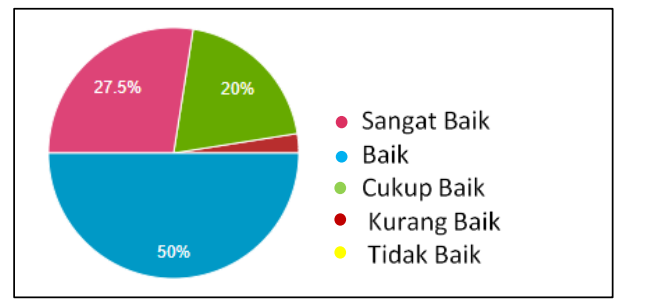

Gambar 6 Diagram Follow Up evaluasi dan Monitoring

Berdasarkan hasil angket evaluasi kinerja lembaga penjaminan IAIM Sinjai dengan indikator follow up evaluasi dan monitoring terdapat $2,5 \%$ kurang baik, $20 \%$ cukup baik, $50 \%$ baik dan $27,5 \%$ sangat baik.

7. Kecepatan pelayanan anggota LPM

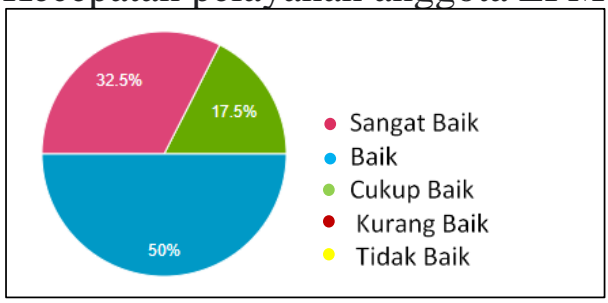

Gambar 7 Diagram Kecepatan Pelayanan anggota LPM

Berdasarkan hasil angket evaluasi kinerja lembaga penjaminan IAIM Sinjai dengan indikator kecepatan pelayanan anggota terdapat $17,5 \%$ cukup baik, 50 $\%$ baik dan $32,5 \%$ sangat baik.

8. Ketepatan Pelaksanan Jadwal Pelayanan

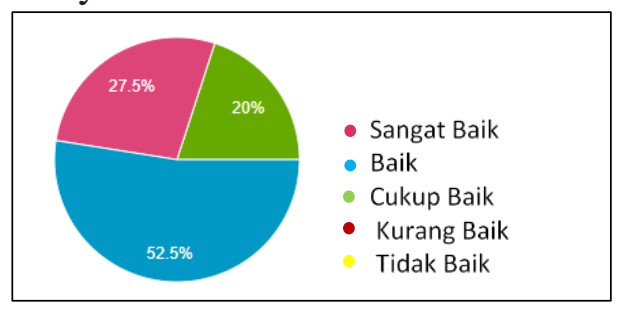

Gambar 8 Diagram Ketepatan Pelaksanaan Jadwal Pelayanan 
Berdasarkan hasil angket evaluasi kinerja lembaga penjaminan IAIM Sinjai dengan indikator ketepatan pelaksanaan jadwal pelayanan terdapat $20 \%$ cukup baik, $52,5 \%$ baik dan $27,5 \%$ sangat baik.

9. Ketepatan Menyelesaikan Tugas

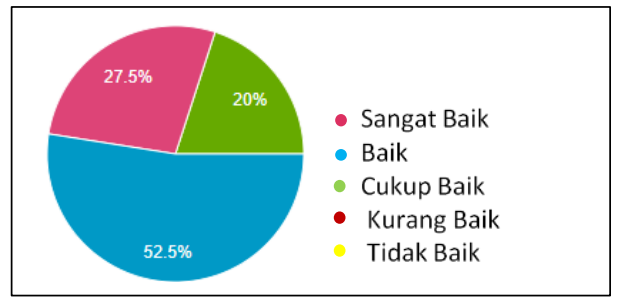

Gambar 9 Diagram Ketepatan Menyelesaikan Tugas

Berdasarkan hasil angket evaluasi kinerja lembaga penjaminan IAIM Sinjai dengan indikator ketepatan menyelesaikan tugasterdapat $20 \%$ cukup baik, $52,5 \%$ baik dan 27,5\% sangat baik.

Berikut ini adalah hasil analisis evaluasi kinerja Lembaga Penjaminan Mutu IAI Muhammadiyah Sinjai semester genap tahun akademik 2019/2020 dari 40 responden.

Tabel 1. Hasil Analisis Kinerja Lembaga Penjaminan Mutu IAI Muhammadiyah Sinjai semseter genap Tahun Akademik 2019/2020

\begin{tabular}{|c|c|c|c|c|c|c|c|c|c|}
\hline \multirow{2}{*}{ No } & \multirow{2}{*}{ BUTIR PERNYATAAN } & \multicolumn{7}{|c|}{ NILAI } & \multirow{2}{*}{$\begin{array}{l}\text { PERNYATAAN } \\
\text { MUTU }\end{array}$} \\
\hline & & $\mathbf{J R}$ & 1 & & 3 & & 5 & $\mathbf{N A}$ & \\
\hline 1 & $\begin{array}{l}\text { Kemampuan staf LPM memenuhi kebutuhan } \\
\text { dokumen }\end{array}$ & 40 & 0 & 0 & 21 & 76 & 56 & 3,83 & Sangat Baik \\
\hline 2 & Kehandalan staff LPM dalam melayani pengguna & 40 & 0 & & & & 52 & 3,73 & Baik \\
\hline 3 & Sosialisasi informasi produk LPM & 40 & 0 & 0 & 33 & 64 & 52 & 3,73 & Baik \\
\hline 4 & Evaluasi dan monitoring pedoman atau standar & 40 & 0 & \begin{tabular}{|l|l}
0 & 3 \\
0
\end{tabular} & 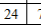 & 72 & 56 & 3,80 & Sangat Baik \\
\hline 5 & $\begin{array}{l}\text { Publikasi hasil evaluasi dan monitoring pedoman } \\
\text { atau standar }\end{array}$ & 40 & 0 & 0 & 21 & 72 & 60 & 3,83 & Sangat Baik \\
\hline 6 & Follow up evaluasi dan monitoring & 40 & 0 & 2 & 24 & 80 & 44 & 3,75 & Baik \\
\hline 7 & Kecepatan pelayanan anggota LPM & 40 & 0 & 0 & 21 & 80 & 52 & 3,83 & Sangat Baik \\
\hline 8 & Ketepatan pelaksanan jadwal pelayanan & 40 & 0 & \begin{tabular}{l|l}
0 & 2 \\
0
\end{tabular} & $24 \mathrm{~s}$ & 84 & 44 & 3,80 & Sangat Baik \\
\hline & Ketepatan menyelesaikan tugas & 40 & 0 & \begin{tabular}{|l|l|l}
0 & &
\end{tabular} & & 84 & 44 & 3,80 & Sangat Baik \\
\hline & DEKS KEPUASAN PELAYANAN LPM & & & & & & & 3,79 & BAIK \\
\hline
\end{tabular}

Ket: JR : Jumlah Responden NA: Nilai akhir

Berdasarkan tabel di atas, rata-rata kepuasan pengguna pada indikator kemampuan staf LPM memenuhi kebutuhan dokumen yaitu 3,83 dengan pernyataan mutu sangat baik. Adapun rata-rata kepuasan pengguna pada indikator kehandalan staf LPM dalam melayani pengguna yaitu 3,73 dengan pernyataan mutu baik. Rata-rata kepuasan pengguna pada indikator sosialisasi informasi produk LPM yaitu 3,73 dengan pernyataan mutu baik. Ratarata kepuasan pengguna pada indikator evaluasi dan monitoring pedoman atau standar yaitu 3,80 dengan pernyataan mutu sangat baik.

Adapun rata-rata kepuasan pengguna pada indikator publikasi hasil evaluasi dan monitoring pedoman atau standar yaitu 3,83 dengan pernyataan mutu sangat baik. Indeks rata-rata kepuasan pengguna pada indikator follow up evaluasi dan monitoring yaitu 3,75 dengan pernyataan mutu baik. Rata-rata kepuasan pengguna pada indikator kecepatan pelayanan anggota LPM yaitu 3,83 dengan pernyataan mutu sangat baik. Rata-rata kepuasan pengguna pada indikator ketepatan pelaksanan jadwal pelayanan yaitu 3,80 dengan pernyataan mutu sangat baik. Rata-rata kepuasan pengguna pada indikator ketepatan menyelesaikan tugas yaitu 3,80 dengan pernyataan mutu sangat baik. Adapun rata-rata kepuasan pengguna terhadap pelayanan Lembaga Penjaminan Mutu Institut agama Islam Muhammadiyah Sinjai semester genap tahun Akademik 2019/2020 yaitu 3,79 dengan pernyataan mutu baik.

Adapun diagramnya dapat dilihat pada gambar berikut.

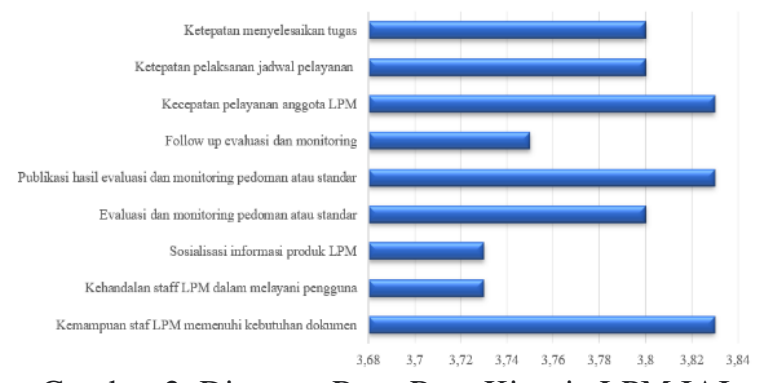

Gambar 2. Diagram Rata-Rata Kinerja LPM IAI

Muhammadiyah Sinjai semester genap tahun Akademik 2019/2020 setiap indikator 
Berdasarkan diagram di atas, indikator yang mendapatkan rata-rata tertinggi adalah kemampuan staf memenuhi kebutuhan dokumen, publikasi hasil evaluasi dan monitoring pedoman atau standar dan kecepatan pelayanan anggota LPM. Sedangkan indikator yang mendapatkan ratarata terendah adalah kehandalan anggota LPM dalam melayani pengguna dan sosialisasi informasi produk LPM. Indikator ini harus ditingkatkan untuk menjamin mutu ke depannya karena proses evaluasi dan monitoring merupakan proses perbaikan secara kontinu. Hal ini senada dengan penelitian Hariyanti bahwa monitoring dan evaluasi kinerja mutlak dilakukan secara terus menerus oleh perguruan tinggi untuk memastikan bahwa proses bisnis yang dijalankannya dapat mencapai tujuan yang telah ditetapkan, melalui strategi pengelolaan yang tepat (Hariyanti et al., 2011).

Hal tersebut dikuatkan oleh pendapat Haryono dkk bahwa proses penjaminan mutu mengidentifikasi aspek pencapaian dan prioritas peningkatan, menyediakan berbagai data sebagai dasar dalam melakukan perencanaan dan pengambilan keputusan serta membantu membangun budaya peningkatan berkelanjutan (Haryono et al., 2019).

Oleh karena itu, kinerja Lembaga Penjaminan mutu harus berada pada kategori baik atau sangat baik. Lembaga ini bertugas untuk menjamin budaya mutu secara kontinu untuk mencapai visi, misi dan tujuan perguruan tinggi tertentu. Evaluasi dan monitoring merupakan tugas utama dari sebuah Lembaga Penjaminan Mutu Perguruan Tinggi yang bertujuan untuk melakukan perbaikan ke depan.

Selain itu, pejaminan mutu sebuah perguruan tinggi akan mempengaruhi peningkatan kinerja komponen atau lembaga lain yang ada dalam perguruan tinggi tersebut. Hal ini senada dengan pendapat Wismaya dalam penelitiannya yang menyatakan bahwa penerapan sistem penjaminan mutu internal dan sistem manajemen mutu ISO memiliki pengaruh bagi peningkatan kinerja organisasi (Wismaya, 2016).

Oleh karena itu, kinerja lembaga penjaminan mutu harus ditingkatkan untuk mendapatkan mutu sebuah perguaran tinggi yang lebih baik. Khususnya kinerja Lembaga Penjaminan Mutu IAI Muhammadiyah Sinjai harus ditingkatkan pada indikator kehandalan anggota LPM dalam melayani pengguna dan sosialisasi informasi produk LPM dan indikator lain harus dipertahankan dan ditingkatkan. Hal ini dikuatkan oleh Sarmidi dalam penelitiannya bahwa proses sosialisasi dokumen yang belum efektif dapat mengakibatkan adanya keterbatasan akses bagi pihak-pihak yang membutuhkan. (Sarmidi, 2019). Selain itu, dalam penelitiannya memberikan solusi penggunaan aplikasi dalam bentuk website yang memungkinkan siapa saja yang berkepentingan dapat mengakses dokumen tersebut dengan mudah.

\section{KESIMPULAN}

Adapun kesimpulan dari hasil penelitian ini adalah rata-rata kinerja Lembaga Penjaminan Mutu IAI Muhammadiyah Sinjai dari semua indikator adalah 3,79 dengan pernyataan mutu baik. Adapun rekomendasi dari pengguna untuk Lembaga penjaminan mutu yaitu meningkatkan profesinalisme untuk peningkatan mutu Institut Agama Islam Muhammadiyah Sinjai, meningkatkan koordinasi dalam kinerja, meningkatkan sosialisasi tentang dokumen penjaminan mutu, peningkatan pelayaanan, serta dapat bersinergi dengan seluruh komponen atau lembaga yang ada pada IAI Muhammadiyah Sinjai.

\section{DAFTAR PUSTAKA}

Arifudin, O. (2019). Manajemen Sistem Penjaminan Mutu Internal (SPMI) Sebagai Upaya Meningkatkan Mutu 
Perguruan Tinggi. Jurnal Ilmiah MEA (Manajemen, Ekonomi, \& Akuntansi), 3(1), 161-169. Retrieved From http://journal.stiemb.ac.id/index.php/m ea.

Gustini, N \& Mauly, Y. (2019). Implementasi Sistem Penjaminan Mutu Internal dalam Meningkatkan Mutu Pendidikan Dasar. Jurnal Islamic Education Manajemen, 4(2), 229-244. https://doi.org/10.15575/isema.v4i2.56 95.

Hariyanti, E., Werdiningsih, I., \& Surendro, K. (2011). MODEL PENGEMBANGAN DASHBOARD UNTUK MONITORING DAN EVALUASI KINERJA PERGURUAN TINGGI. JUTI: Jurnal Ilmiah Teknologi

Informasi.https://doi.org/10.12962/j240 68535.v9i1.a63

Haryono, Budiyono, Istyarini, Wardi, \& Apri A. (2019). Sistem Penjaminan Mutu Pendidikan dalam Meningkatkan Mutu Pendidikan Sekolah Dasar di Kecamatan Gajah Mungkur Kota Semarang. Jurnal Panjar 1 (1), 17-22.

Jamaluddin, J. \& Sopiah, S. (2018). Desain Sekolah Model: Studi Penjaminan Mutu Pendidikan. IJER (Indonesian Journal of Educational Research), 2(2), 99. https://doi.org/10.30631/ijer.v2i2.47.

Nurjannah, N. (2020). Evaluasi Kepuasan Mahasiswa Terhadap Pelayanan Akademik Fakultas Tarbiyah dan Ilmu Keguruan Iai Muhammadiyah Sinjai. Jurnal Evaluasi Pendidikan, 11(2), 51 57.https://doi.org/10.21009/10.21009/J EP.0122.

Permendikbud No. 3 tahun 2020 tentang Standar Nasional Pendidikan Tinggi

Peraturan Menteri Riset Teknologi dan Pendidikan Tinggi No. 62 Tahun 2016 tentang Sistem Penjaminan Mutu Pendidikan Tinggi. Retrieved from https://bpm.uai.ac.id/wpcontent/uploads/2019/12/permenristek dikti-nomor-62-tahun-2016-tentangspmi-salinan.pdf.
Rusman. (2009). Manajemen Kurikulum, Seri Manajemen Sekolah Bermutu. Jakarta: Raja Grafindo Persada.

Sarmidi. (2019). Perancangan Aplikasi Audit Mutu Internal Pada Penerapan Sistem Penjaminan Mutu Internal ( SPMI ) Stmik Tasikmalaya Berbasis Web. Informatics and Digital Expert (Index).

Suci, A. (2017). Penjaminan Mutu Perguruan Tinggi: Dilema Politik Organisasi dan Urgensi Penggunaan Profesional Eksternal. Jurnal Penjaminan Mutu, 3(2), 215-222.

Sulaiman, A \& Wibowo, U.B. (2016). Implementasi Sistem Penjaminan Mutu Internal Sebagai Upaya Meningkatkan Mutu Pendidikan Di Universitas Gadjah Mada. Jurnal Akuntabilitas Manajemen Pendidikan, 4(1), 17-32. Retrieved from

http://journal.uny.ac.id/index.php/jamp

Trianto, D. (2020). Evaluasi Siklus Pelaksanaan Standar dalam Sistem Penjaminan Mutu Internal (SPMI) di STT Bethel Indonesia. Jurnal Penjaminan Mutu, 6(2), 134-145.

Triyana, I.G.N. (2017). Penjaminan Mutu Pendidikan Melalui Teknologi Informasi di Institut Hindu Dharma Negeri Denpasar. Jurnal Penjaminan Mutu, 3(1), 119-126.

Umami, M. (2019). Manajemen Penjaminan Mutu Internal Pendidikan di Sekolah Menengah Kejuruan 2 Al Hikmah 1 Benda Sirampog Brebes. Tesis IAIN Purwokerto. Retrieved from http://repository.iainpurwokerto.ac.id/6 254/1/cover_abstrak_dafta\%20isi_bab $\% 20 \mathrm{i}$ bab\%20v_daftar\%20pustaka.pdf

Wismaya, P. B. A. (2016). Pengaruh Sistem Penjaminan Mutu Internal dan Sistem Manajemen Mutu ISO 9001:2008 terhadap Kinerja Organisasi di Universitas Warmadewa. Jurnal Administrasi Publik. 